\title{
STIMULASI DAN DETEKSI DINI TUMBUH KEMBANG BALITA USA 9 - 12 BULAN MENGGUNAKAN APLIKASI TUMBUH KEMBANG BALITA DI WILAYAH KELURAHAN MARGADANA
}

\author{
Nilatul Izah ${ }^{1}$, Ratih Sakti Prastiwi² Istiqomah Dwi Andari $^{3}$ \\ 1,2,3 Program Studi Diploma III Kebidanan Politeknik Harapan Bersama \\ e-mail: ${ }^{1}$ nilaizah12@gmail.com, ${ }^{2}$ ratih.sakti@ymail.com, ${ }^{3}$ istyandari44@gmail.com
}

\begin{abstract}
Abstrak
Pertumbuhan dan perkembangan merupakan dua peristiwa yang berbeda tetapi tidak bisa dipisahkan. Pembinaan tumbuh kembang anak secara komprehensif dan berkualitas yang diselenggarakan melalui kegiatan stimulasi, deteksi dan intervensi dini penyimpangan tumbuh kembang balita dilakukan pada periode 5 (lima) tahun pertama kehidupan anak. Hasil Riskesdas (2013) menunjukan sebanyak 34,3\% orangtua tidak melakukan pemantauan tumbuh kembang, lebih tinggi dibandingkan hasil Riskesdas tahun 2007 sebanyak 25,5\%, yang menunjukan masih tingginya anak yang belum terpantau tumbuh kembangnya. Sehubungan dengan hal tersebut maka diperlukan suatu program yang mendukung tingkat pengetahuan ibu balita khusunya yang berusia 9 - 60 bulan dalam melakukan deteksi dini pertumbuhan dan perkembangan balita agar keterlambatan dalam pertumbuhan dan perkembangan balita dapat diatasi sedini mungkin. Tujuan dari pengabdian ini untuk meningkatkan pengetahuan dan ketrampilan ibu balita dalam melakukan stimulasi tumbuh kembang anaknya serta meningkatkan kemampuan ibu dalam melakukan deteksi dini gangguan pertumbuhan dan perkembangan balita. Kegatan pengabdian dilaksanakan selama 2 hari yaitu pd tanggal 1 dan 4 Maret 2019 yg diikuti oleh 27 orang ibu. Hasil pengabdian pada masyarakat ibu balita yang telah mendapatkan pendidikan kesehatan antusias untuk memantau pertumbuhan dan perkembangan anaknya, ibu balita mengetahui dan memahami cara menggunakan aplikasi tumbuh kembang yang di berikan oleh tim pengabdian kepada masyarakat.
\end{abstract}

Kata kunci : Stimulas, Deteksi, Tumbuh Kembang, Smartphone.

\section{PENDAHULUAN}

Pertumbuhan dan perkembangan merupakan dua peristiwa yang berbeda tetapi tidak bisa dipisahkan. Pertumbuhan dan perkembangan pada anak adalah manifestasi dari berbagai interaksi yang kompleks antara faktor internal dan faktor eksternal. Pemberian gizi yang optimal selama masa bayi dan balita sangat penting karena pada periode ini ditandai cepatnya pertumbuhan dan perkembangan anak. Pada bayi memiliki kebutuhan substansi penting untuk energi dan nutrisi, karena untuk perkembangan perkembangan struktural dan fungsional otak. 
Pertumbuhan pada anak dapat diukur menggunakan antropometri. Instrumen antropometri yang digunakan untuk mengetahui pertumbuhan anak diantaranya adalah menggunakan standar WHO growth charts.Perkembangan anak terjadi pada beberapa aspek seperti perkembangan sosial, perkembangan emosional, dan perkembangan kognitif. Salah satu cara pengukuran perkembangan anak yang sistematis, komprehensif, efektif dan efisien adalah dengan Kuesioner Pra Skrining Perkembangan (KPSP).

Proses penanganan perkembangan anak yang paling efektif adalah memberikan pengalaman belajar langsung kepada anak dan keluarga, dengan durasi yang lebih lama, kualitas yang tinggi, dan intensitas yang tinggi, serta terintegrasi dengan keluarga, tenaga kesehatan, gizi dan juga sistem pendidikan (Engle et al., 2007) Pemantauan tumbuh kembang anak sangat memerlukan partisipasi keluarga, dengan deteksi dini oleh orangtua dapat mengidentifikasi $1-6 \%$ anak yang mengalami gangguan tumbuh kembang. Salah satu cara deteksi dini pertumbuhan dan perkembangan anak yang efektif dan efisien dapat menggunakan media aplikasi yang berbasis internet (Bert, Giacometti, Gualano, \& Siliquini, 2014; De Onis, Wijnhoven, \& Onyango, 2004). Penggunaan smartphone telah menjadi hal penting bagi dunia kesehatan. Penggunaan smartphone sangat membantu dalam layanan kesehatan, promosi kesehatan, dan meningkatkan derajat kesehatan. (Patrick, Griswold, Raab, \& Intille, 2009) Seperti halnya penggunaan aplikasi smartphone untuk pemantauan tumbuh kembang anak bermanfaat menyediakan informasi tentang stimulasi pada anak, menyediakan panduan dalam stimulasi tumbuh kembang anak, mempermudah bidan dalam memberikan konseling tumbuh kembang anak, serta dalam pendokumentasian tumbuh kembang anak.

Pembinaan tumbuh kembang anak secara komprehensif dan berkualitas yang diselenggarakan melalui kegiatan stimulasi, deteksi dan intervensi dini penyimpangan tumbuh kembang balita dilakukan pada periode 5 (lima) tahun pertama kehidupan anak sebagai "masa keemasan (golden period) atau jendela kesempatan (window opportunity), atau masa kritis (critical period)". Periode 5 (lima) tahun pertama kehidupan anak (masa balita) merupakan masa pertumbuhan dan perkembangan yang paling pesat pada otak manusia dan merupakan masa yang sangat peka bagi otak anak dalam menerima berbagai masukan dari lingkungan sekitarnya. Pada masa ini otak balita bersifat lebih plastis dibandingkan dengan otak orang dewasa dalam arti anak balita sangat terbuka dalam menerima berbagai macam pembelajaran dan pengkayaan 
baik yang bersifat positif maupun negatif. Sisi lain dari fenomena ini yang perlu mendapat perhatian yaitu otak balita lebih peka terhadap asupan yang kurang mendukung pertumbuhan otaknya seperti asupan gizi yang tidak adekuat, kurang stimulasi dan kurang mendapatkan pelayanan kesehatan yang memadai (Departemen Kesehatan RI, 2014; IDAI, 2016). Mengingat masa 5 tahun pertama merupakan masa yang relatif pendek dan tidak akan terulang kembali dalam kehidupan seorang anak, maka para orang tua, pengasuh, dan pendidik harus memanfaatkan periode yang singkat ini untuk membentuk anak menjadi bagian dari generasi penerus yang tangguh dan berkualitas. Salah satu yang dapat dilakukan yaitu dengan memerhatikan tumbuh kembang anak. Tumbuh kembang optimal adalah tercapainya proses tumbuh kembang yang sesuai dengan potensi yang dimiliki oleh anak. Dengan mengetahui penyimpangan tumbuh kembang secara dini, maka dapat dilakukan berbagai upaya pencegahan, stimulasi dan penyembuhan serta pemulihannya sedini mungkin pada masa-masa proses tumbuh kembang anak sehingga hasil yang diharapkan akan tercapai. Terdapat beberapa upaya yang dapat dilakukan untuk membantu agar anak tumbuh dan berkembang secara optimal. Hal tersebut dilakukan dengan cara deteksi adanya penyimpangan dan intervensi dini yang perlu dilaksanakan oleh semua pihak mulai dari tingkat keluarga, petugas kesehatan (mulai dari kader kesehatan sampai dokter spesialis), dan di semua tingkat pelayanan kesehatan mulai dari tingkat dasar sampai pelayanan yang lebih spesialistis.

Hasil Riskesdas (2013) menunjukan sebanyak 34,3\% orangtua tidak melakukan pemantauan tumbuh kembang, lebih tinggi dibandingkan hasil Riskesdas tahun 2007 sebanyak 25,5\%, yang menunjukan masih tingginya anak yang belum terpantau tumbuh kembangnya (Dinas Kesehatan Republik Indonesia, 2013). Pengetahuan orangtua juga berkorelasi dengan tingkat stimulasi yang diberikan orangtua terhadap anaknya, dimana semakin tinggi pengetahuan tentang stimulasi terhadap anak maka semakin sering melakukan stimulasi tumbuh kembang terhadap anak, sebaliknya semakin rendah tingkat pengetahuan tentang stimulasi terhadap anak maka semakin kurang melakukan stimulasi tumbuh kembang terhadap anak, hal inilah yang dapat mengurangi tingkat kepatuhan orangtua dalam melakukan stimulasi tumbuh kembang terhadap anak. Pengetahuan orangtua akan berkorelasi dengan keterampilan orangtua dalam memberikan stimulasi tumbuh kembang anak, keterampilan orangtua dalam pengasuhan dan keterampilan dalam stimulasi tumbuh kembang berpengaruh terhadap kecepatan pertumbuhan dan perkembangan anak, pada orangtua yang kurang terampil 
akan menyebabkan orangtua tidak mampu memberikan stimulasi tumbuh kembang anak.

Data Riskesdas (2013) menyebutkan bahwa status gizi balita Indonesia menurut indikator BB/U prevalensi berat kurang (gizi buruk dan gizi kurang) secara nasional adalah 19,6 persen. Terjadi peningkatan dibandingkan tahun 2010 sebesar 17,9\% dan tahun 2007 sebesar 18,4\%. Angka kejadian gangguan perkembangan pada anak diketahui sekitar $33,5 \%$ anak, dimana $22,1 \%$ anak mengalami gangguan perkembangan dan $11,4 \%$ anak mengalami perkembangan yang meragukan.

Gangguan perkembangan pada anak di Indonesia adalah keterlambatan atau gangguan dalam perkembangan bicara $46,8 \%$ dan perkembangan gerak yang terlambat 30,9\%. Prevalensi gangguan perkembangan pada anak di Indonesia belum teridentifikasi secara nasional. Tingginya prevalensi gangguan perkembangan yang disebabkan keterlambatan perkembangan sebanyak 8,6\%. Beberapa anak dapat mengalami keterlambatan pertumbuhan dan perkembangan yang memerlukan program penanganan supaya bisa beradaptasi untuk bisa mencapai tingkat perkembangan diumurnya tersebut.

Sehubungan dengan hal tersebut maka diperlukan suatu program yang mendukung tingkat pengetahuan ibu balita khusunya yang berusia $9-60$ bulan dalam melakukan deteksi dini pertumbuhan dan perkembangan balita agar keterlambatan dalam pertumbuhan dan perkembangan balita dapat diatasi sedini mungkin. Berdasarkan hal tersebut kami akan melakukan pendidikan kesehatan guna meningkatkan pengetahuan dan ketrampilan ibu balita yang berusia 9 - 60 bulan dengan menggunakan aplikasi tumbuh kembang balita di wilayah kerja Puskesmas Margadana Kota Tegal. Pengabdian kepada masyarakat ini bertujuan meningkatkan pengetahuan dan ketrampilan ibu balita usia 9 - 60 bulan dalam melakukan stimulasi tumbuh kembang anaknya serta eningkatkan kemampuan ibu balita usia 9 - 60 bulan dalam melakukan deteksi dini gangguan pertumbuhan dan perkembangan balita.

\section{METODE}

Kegiatan pengabdian kepada masyarakat mengenai Stimulasi dan Deteksi Dini Tumbuh Kembang Balita Usia 9-12 Bulan Menggunakan Aplikasi Tumbuh Kembang Balita di Wilayah Kelurahan Margadana ini diberikan pada ibu - ibu yang memiliki balita khususnya yang berusia 9 - 60 bulan yang berdomisili di Kelurahan Margadana. 
Kegiatan pengabdian kepada masyarakat ini didanai oleh Institusi yaitu Politeknik Harapan Bersama. Proses pelaksanaan kegiatan pengabdian melalui beberapa tahap, yaitu:

1. Mengurus perijinan dengan Bappeda, Puskesmas dan Kelurahan

2. Koordinasi dengan bidan dan Kader setempat terkait peserta yang akan mengikuti kegiatan pengabdian kepada masyarakat

3. Memberikan informasi kepada masyarakat

4. Mengumpulkan peserta dan melakukan pendidikan kesehatan

Kegiatan Pengabdian Pada Masyarakat pendidikan kesehatan dan pelatihan pada ibu yang memiliki balita khususnya usia $9-60$ bulan di wilayah Kelurahan Margadana Kota Tegal. Pengabdian masyarakat dilaksanakan selama 2 hari pada tanggal 1 dan 4 Maret 2019. Peserta yang mengikuti kegiatan ini sesuai dengan yang diharapkan diproposal yaitu sebanyak 27 ibu yang memiliki balita usia 9 - 60 bulan yang tinggal di wilayah Puskesmas Margadana.

Kegiatan ini diawali dengan menilai sejauh mana pengetahuan ibu tentang tumbuh kembang balita melalui pertanyaan - pertanyaan yang diajukan tim sebelum melakukan sosialisasi, kegiatan dilanjutkan dengan mengenalkan ibu - ibu tentang aplikasi tumbuh kembang beserta isi dari aplikasi yang dapat diterapkan oleh ibu - ibu pada anaknya. Setelah dilakukan sosialisasi tim memberikan aplikasi tumbuh kembang pada smartphone ibu - ibu dan mengajarkan bagaimana cara menggunakan aplikasi tersebut. Setelah para ibu mengetahui tim melakukan evaluasi tentang cara penggunaan serta meminta ibu - ibu untuk mengisi kuesioner yang berhubungan dengan penilaian terhadap aplikasi tersebut
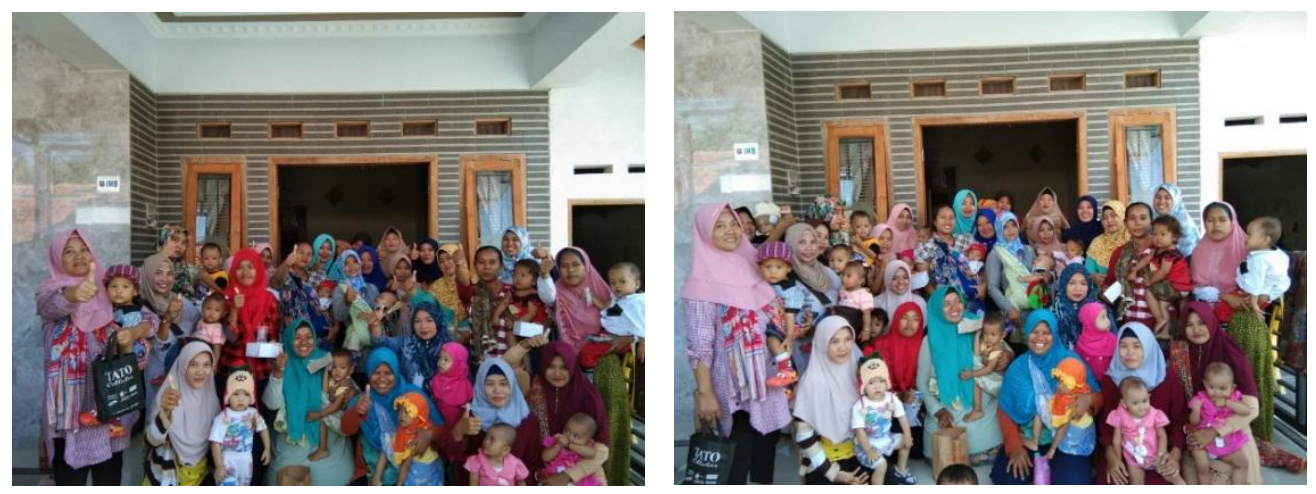

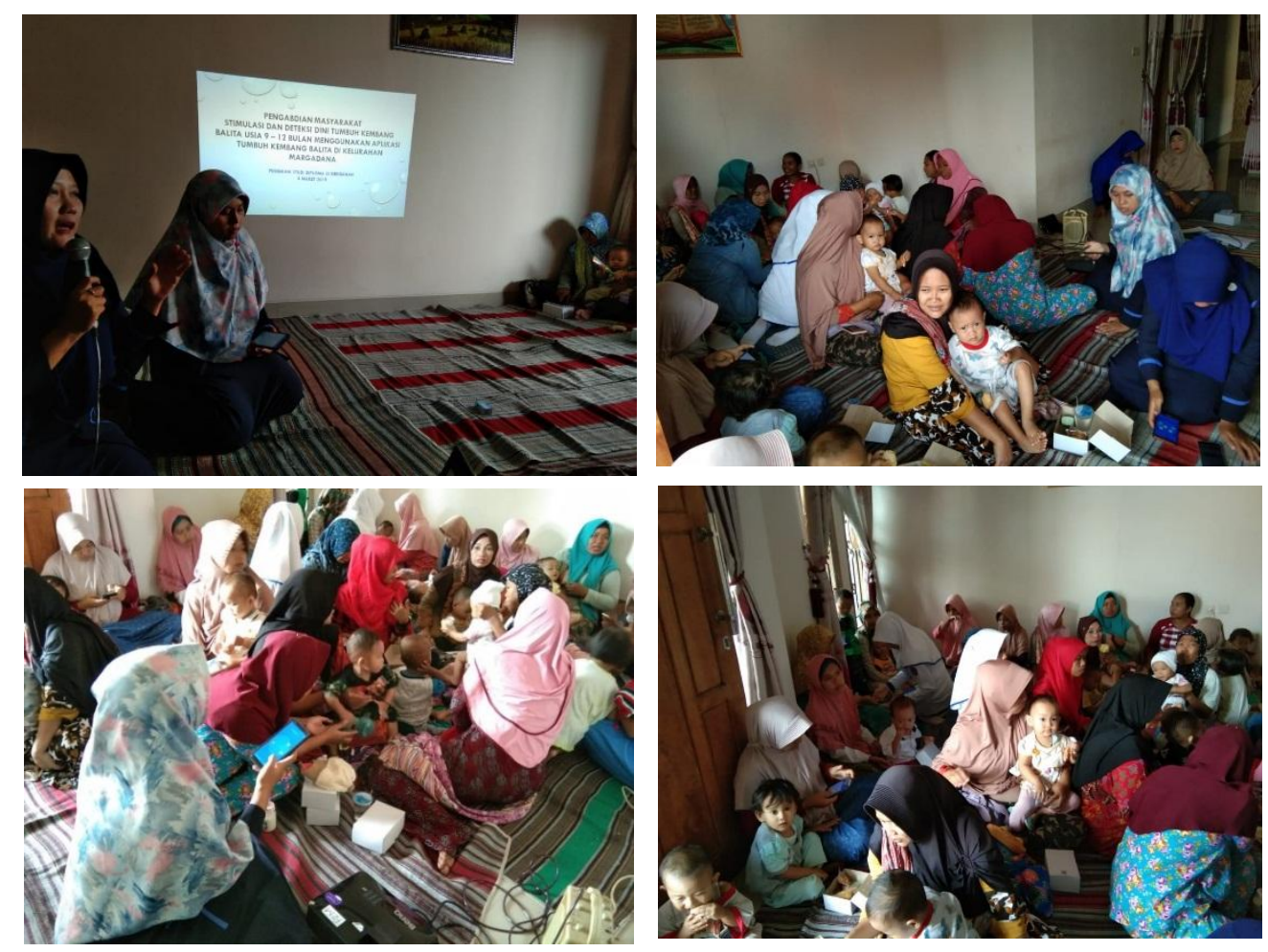

Gambar 1: Pengabdian masyarakat Stimulasi dan Deteksi Dini Tumbuh Kembang Balita usia $9-60$ bulan

\section{HASIL DAN PEMBAHASAN}

Kegiatan Pengabdian Pada Masyarakat pendidikan kesehatan dan pelatihan pada ibu yang memiliki balita khususnya usia $9-60$ bulan di wilayah Kelurahan Margadana Kota Tegal. Pengabdian masyarakat dilaksanakan selama 2 hari pada tanggal 1 dan 4 Maret 2019. Peserta yang mengikuti kegiatan ini sesuai dengan yang diharapkan diproposal yaitu sebanyak 27 ibu yang memiliki balita usia 9 - 60 bulan yang tinggal di wilayah Puskesmas Margadana.

Kegiatan ini diawali dengan menilai sejauh mana pengetahuan ibu tentang tumbuh kembang balita melalui pertanyaan - pertanyaan yang diajukan tim sebelum melakukan sosialisasi, kegiatan dilanjutkan dengan mengenalkan ibu - ibu tentang aplikasi tumbuh kembang beserta isi dari aplikasi yang dapat diterapkan oleh ibu - ibu pada anaknya. Setelah dilakukan sosialisasi tim memberikan aplikasi tumbuh kembang pada smartphone ibu - ibu dan mengajarkan bagaimana cara menggunakan aplikasi tersebut. Setelah para ibu mengetahui tim melakukan evaluasi tentang cara penggunaan serta meminta ibu - ibu untuk mengisi kuesioner yang berhubungan dengan penilaian terhadap aplikasi tersebut. 
Keberhasilan kegiatan ini tidak terlepas dari adanya dukungan dari Kepala Puskesmas serta bidan di wilayah Puskesmas Margadana yang telah memfasilitasi tim pelaksana untuk berkomunikasi dengan peserta kegiatan. Selain itu adanya bantuan dari kader dan keantusiasan peserta dalam kegiatan ini sehingga kegiatan dapat berjalan dengan lancar. Namun kegiatan ini juga tidak lepas dari adanya kekurangan seperti keterlambatan peserta menghadiri kegiatan sehingga peserta yang sudah hadir tepat waktu harus menunggu peserta yang terlambat dan kegiatan harus dilaksanakan dalam waktu yang lebih terbatas

\section{KESIMPULAN}

Hasil pengabdian pada masyarakat dalam bentuk Ipteks bagi Masyarakat (IbM) yang telah dilaksanakan dapat disimpulkan sebagai berikut:

a. Ibu balita yang telah mendapatkan pendidikan kesehatan antusias untuk memantau pertumbuhan dan perkembangan anaknya

b. Ibu balita mengetahui dan memahami cara menggunakan aplikasi tumbuh kembang yang di berikan oleh tim pengabdian kepada masyarakat

c. Ibu balita yang telah mendapatkan informasi dan pelatihan deteksi dini tumbuh kembang balita bersedia

\section{SARAN}

Pendidikan kesehatan stimulasi sekaligus deteksi dini pertumbuhan dan perkembangan ini sangat perlu di lakukan, hal ini dilakukan sebagai upaya untuk mencegah terjadinya gangguan pertumbuhan dan perkembangan pada balita khususnya kejadian stunting. Selain pada ibu perlu juga dilakukan pada kader. Kader dan ibu yang sudah mendapatkan pelatihan diharapkan mau memberikan informasi tersebut pada saudara dan masyarakat. 


\section{DAFTAR PUSTAKA}

[1] Departemen Kesehatan RI, Situasi HIV/AIDS di Indonesia tahun 1987-2006, 2007.

[2] BKKBN, Buku sumber untuk advokasi Direktorat Advokasi dan KIE. BKKBN, UNFPA, Bank Dunia, ADB, dan STARH, 2003.

[3] Basri, H, Remaja Berkualitas Problematika Remaja dan Solusinya, Pustaka Pelajar, Yogyakarta. 2000

[4] Kemenkes RI, Statistik Kasus HIV/ AIDS di Indonesia, Jakarta: Kemenkes RI, 2014.

[5] Dinas Kesehatan Kota Tegal, Profil Dinas Kesehatan Kota Tegal, 2017.

[6] Depkes RI, Pedoman Pelayanan Kesehatan Peduli Remaja di Puskesmas, Direktorat Kesehatan Keluarga Dirjen Bina Kesehatan Masyarakat, Jakarta, 2005.

[7] Iryanti, Tesis : Pengaruh Pendidikan Kesehatan Reproduksi Melalui Metode Pendidikan Sebaya Terhadap Pengetahuan dan Sikap Remaja dalam Pencegahan KTD di SMKN 15 Bandung, UGM, 2003.

[8] Basri, H, Remaja Berkualitas Problematika Remaja dan Solusinya, Pustaka Pelajar, Yogyakarta, 2000 